\title{
GENDER ROLE IN SCHOOL BULLYING
}

\author{
D Neupane ${ }^{1 *}$ \\ ${ }^{1} \mathrm{PhD}$ Fellow, Dr KN Modi University, Rajasthan, India. \\ *Correspondence to: Mr Dasarath neupane, Dr KN Modi University, Rajasthan, India. \\ Email: neupane.dasarath@gmail.com
}

\begin{abstract}
School bullying with reference to gender was performed in Kathmandu. The general aim of this research was to analyze the relationship between bullying and victimization with response to gender among Nepalese school adolescents. The study was correlational in design employing a pen-and-paper self-report survey. Within the survey, two separate instruments measured the criterion variables bullying and victimization. Participants were drawn from three private schools of Kathmandu. These schools were chosen in random selection. The number of participations was 104 school students. The study investigated the prevalence of bullying in the school with reference to gender. The result from the survey indicates that the boys are more bully than girls are. Boys have reported higher mean scores of physical bullying, verbal bullying, physical victimization and verbal victimization. On the other hand, girls have reported higher mean scores of indirect bullying and victimization. Gender differences in bullying and victimization were as expected and as social role theory and previous research would predict, with boys reporting higher direct and overall levels of bullying and victimization than girls. Similarly, and in accordance with the literature, girls reported higher levels of indirect bullying and victimization than boys are.
\end{abstract}

Key Words: Bullying, Gender role, Victimization.

\section{INTRODUCTION}

Bullying is defined as repeated oppression, physical or mental, of a less powerful person by a more powerful person or group of persons. It occurs where there is an imbalance in power between people, and it is a persistent or continued unwelcome behavior. It is a kind of behaviour characterized by intentionality and hurtfulness. Negative actions can be physical contact (such as hitting or kicking), words (e.g., teasing, and calling names), or obscene gestures or facial expressions. Negative actions also include the intentional exclusion of a student and the spreading of rumors.

There is no universally agreed-upon definition of bullying; however, Dan Olweus, who is considered the "pioneer in bullying research" " has defined bullying, or peer victimization, in a way that has been generally well-received and widely used. According to Olweus (1994), bullying occurs when a student is "exposed, repeatedly over time, to negative actions on the part of one or more other students". ${ }^{2}$ A negative action is when someone either attempts to, or intentionally inflicts, discomfort or injury on another student. This can be achieved through several means. Negative actions also include the intentional exclusion of a student and the spreading of rumors. This way, "bullying cannot apply to a conflict between students of equal physical, mental, or emotional strength". ${ }^{1}$ Similarly, "Bullying is a form of peer abuse that includes acts of aggression in which one or more students physically and/or psychologically harass a weaker victim". ${ }^{3}$ The cause of bullying is only the imbalance of power. It has both physical and psychological effects upon victim. With the increasing public concern about school safety, researchers have broadened the definition of school violence to include "any conditions or acts that create a climate in which individual students and teachers feel fear or intimidation in addition to being the victims of assault, theft, or vandalism". ${ }^{4}$ For Batsche, bullying creates a fearful climate to students and teachers.

P.T. Slee says that victims of bullying suffer from "a loss of self-esteem lasting long into their adult life". ${ }^{5}$ Bullying does not effect for the timing. It creates long-term effect upon victims. Victims of bullying suffer from a loss of self-esteem into their adult life. According to Farrington bullies in school are very likely to bully their spouses and children later. He argues that "society is the utmost victim of bullying because bullies in school are very likely to bully their spouses and children later, which perpetuates the cycle of domestic violence and creates new generations of aggressive children". 6 Thus, bullying has long term effect. It creates cycle of domestic violence which can be seen even in new generations.

Bullying and victimization among youth have received increased attention in recent years by researchers and educators internationally. Researchers have found that these phenomena are widespread among school-age children across several countries in Europe, ${ }^{7}$ North America ${ }^{8}$ and Oceania. ${ }^{9}$ Thus, 
the purpose of the current study was to examine bullying and victimization among school-age children in Kathmandu, Nepal.

\section{Correlates of Bullying and Victimization}

Gender predicts bullying and victimization. "Boys in Europe and the United States report more bullying as perpetrators and as victims than do girls". "Generally, boys engage in physical and direct bullying, such as pushing, shoving, or kicking, whereas girls engage in verbal and indirect bullying, such as intentional exclusion from the group, spreading rumors, teasing, or name calling" (Almeida 178). According to Lane, "[b]ullying for boys is more likely to be part of power-based social relationships and for girls affiliation activities are more frequently the source of bullying activities". ${ }^{11}$ Such differences seem to originate in early gender socialization. The literature on physical play activity suggests that boys "engage much more often in rough-andtumble play than girls do in virtually all cultures studied". ${ }^{2}$

\section{Different Types of Bullying}

Different researchers have categorized bullying into different types. Björkqvist and Niemelä suggest that "bullying can be categorized into the dichotomies physical versus verbal and direct versus indirect". ${ }^{14}$ On another much related research bullying is categorized into three types "direct physical, direct verbal and indirect aggression". ${ }^{13}$ Physical bullying includes such direct behaviors as pushing another, hitting, punching, or kicking. Verbal bullying may take the form of yelling abuse at another, name-calling, using insulting expressions, or make verbal threats. On the other hand, indirect bullying refers to the behavior such as spreading malicious rumors about another, excluding a person from the group, or disclosing another's secrets to a third person. Taking all of this into account, the present study used the physical, verbal and indirect bullying definitions of Björkqvist, Niemelä et al. (1992) as stated above, particularly as these constructs have been "widely used in aggression and bullying research in many countries". ${ }^{14}$ Having briefly outlined the different forms of aggression and bullying, the discussion will now turn to the associations between gender, age and aggression.

\section{Gender and Aggression}

In explaining sex differences in social behaviour, Eagly (1987) proposed a social role theory, whereby "people behave in a manner that is consistent with their gender roles". ${ }^{15}$ These roles have arisen from social divisions relating to domestic and workrelated roles, such that females primarily carry out domestic and child rearing duties and are more likely to fill positions in the workplace that are communal in nature (e.g., nurse, teacher). Through experiencing and enacting gender roles, males and females develop different skills, attitudes, and expectancies resulting in behavior patterns that differ according to those gender-roles. Consequently, there are "normative expectations that males are more agentic (instrumental, masculine) and females are more communal (expressive, feminine), with these gender norms passed on through socialization processes to future generations". ${ }^{16}$

Consequently, it is necessary to review a variety of studies specifically relating to gender differences in indirect aggression in children and young people. There are numerous studies showing that adolescent girls typically exhibit more indirect aggressive behavior than boys. In a large cross-cultural study of aggression in 8-, 11-, and 15-year-old children $(\mathrm{N}=2,094)$, peer-estimations (participants estimate the extent to which peers behave in certain ways) showed that between $41 \%$ and $55 \%$ of girls' aggressive behaviors were indirect, whereas the proportion for boys ranged between $20 \%$ and $26 \% .{ }^{17}$ The proportions of verbal aggression for girls varied between $31 \%$ and $40 \%$ (boys $37-47 \%$ ), and from $8 \%$ to $20 \%$ for physical aggression (boys 33-37\%). Other studies using peer-nomination (students name peers who display certain behaviors) and peer-ratings (students estimate the frequency that named classmates perform aggressive acts) have also found that girls exhibit more indirect aggressive behavior than boys. ${ }^{18}$ The above findings correspond with Australian research which used a peer-estimation technique whereby adolescent participants were asked to estimate how often fellow students in their class behaved in specific ways to others (girls to girls and boys to boys).

\section{General objective}

The general aim of this research was to analyze the relationship between bullying and victimization with response to gender among Nepalese school adolescents.

The specific objectives of this research can be described as:

- To build knowledge based on the phenomena of bullying and victimization with reference to gender in school level.

\section{Hypotheses}

Gravetter and Forzano (19) mention that before a research idea can be evaluated, it needs to be transformed into hypotheses. These hypotheses are statements about the relationship between variables. The hypotheses of this study are as follow:

- Gender role is significant in bullying and victimization.

1. Boys would report significantly higher mean scores of physical bullying than girls.

2. Boys would report significantly higher mean scores of physical victimization than girls.

3. Boys would report significantly higher mean scores of verbal bullying than girls.

4. Boys would report significantly higher mean scores of verbal victimization than girls.

5. Girls would report significantly higher mean scores of indirect bullying than boys.

6. Girls would report significantly higher mean scores of indirect victimization than boys.

\section{MATERIALS AND METHODS \\ Design and Participants}

The study was correlational in design employing a pen-and-paper self-report survey. Within the survey, two separate instruments measured the criterion variables bullying and victimization. There are a number of methodological considerations, beginning with issues surrounding the consent procedures and the form of survey (i.e., self-report) employed in the present study that require consideration. Participants were drawn from three private schools (Trilok Children's Academy, Balaju, Kathmandu, Deepjyoti Boarding High School, Gongabun, Kathmandu and Navodit Vidhya Kunja Higher Secondary School, Samakhushi, Kathmandu). These schools were chosen in random selection. 
The respondents were between 14 years to 17 years. The total number of students was 104. Among them 20 were from grade 9 and 84 were from grade 10 . Among them 20 were 14 years, 35 were 15 years, 39 were 16 years, and 10 were 17 years old. The following table no. 1 illustrates the data of respondent's grade and age.

Table 1: Respondent's Grade * Respondent's Age Crosstabulation

\begin{tabular}{|c|c|c|c|c|c|c|}
\hline & \multicolumn{4}{|c|}{ Respondent's Age } & \multirow[t]{2}{*}{ Total } \\
\hline & & 14 & 15 & 16 & 17 & \\
\hline \multirow{2}{*}{$\begin{array}{l}\text { Respondent's } \\
\text { Grade }\end{array}$} & 9 & 13 & 7 & 0 & 0 & 20 \\
\hline & 10 & 7 & 28 & 39 & 10 & 84 \\
\hline \multicolumn{2}{|l|}{ Total } & 20 & 35 & 39 & 10 & 104 \\
\hline
\end{tabular}

Among them, 60 were boys and 44 girls. On the basis of age, 7 boys and 3 girls of 17 years old were participated. Out of 39 respondents of 16 years, 28 were boys and 11 girls. There were 35 respondents who were 15 years. Among them, 16 were boys and 19 girls. Similarly, 9 boys and 11 girls were of 14 years. The following table no. 2 shows the data of respondents' grade, age and gender. The sample comprised 44 girls (41.7\%) and 60 boys $(58.3 \%)$, with Table 2 presenting more detailed descriptive statistics for participating students.

Table 2:

\begin{tabular}{|l|c|c|}
\hline Respondent's Gender & $\mathrm{N}$ & \% of Total Sum \\
\hline Boys & 60 & $58.3 \%$ \\
\hline Girls & 44 & $41.7 \%$ \\
\hline Total & 104 & $100.0 \%$ \\
\hline
\end{tabular}

\section{Materials}

All constructs were measured using pen-and-paper self-report questionnaires. Each of the two scales began on a separate page with its own preamble to introduce the scale, resulting in a questionnaire battery including an instruction/cover sheet. In the case of scales of bullying and victimization, the 24-item Direct and Indirect Aggression Scales (13) measures three types of aggression: Physical (7 items; e.g., hits, kicks, trips), Verbal (5 items; e.g., yells at or argues, insults), and Indirect (12 items; e.g., ignores, tells bad or false stories).
The bully and victim questionnaire subscales were used in the study. The following table no 3 shows in detailed.

Table 3: Pilot Study Bully and Victim Questionnaire Subscales

\begin{tabular}{|c|c|c|}
\hline Physical & Verbal & Indirect \\
\hline $\begin{array}{l}\text { 1. hit } \\
\text { 6. kick } \\
\text { 9. trip } \\
\text { 14. shove } \\
\text { 18. take things } \\
\text { 22. push } \\
\text { 24. grab }\end{array}$ & $\begin{array}{l}\text { 4. yell } \\
\text { 8. insult } \\
\text { 11. threaten to hurt } \\
\text { 16. call names } \\
\text { 20. tease }\end{array}$ & $\begin{array}{l}\text { 2. prank phone call } \\
\text { 3. shut out of the group } \\
\text { 5. make friends with others as } \\
\text { revenge } \\
\text { 7. ignore } \\
\text { 10. bad stories } \\
\text { 12. nasty electronic messages } \\
\text { 13. plan secretly to bother } \\
\text { 15. talk behind back } \\
\text { 17. say "let's not be with ..." } \\
\text { 19. tell secrets } \\
\text { 21. write criticizing notes } \\
\text { 23. criticize clothes, hair } \\
\text { 25. dirty looks, draggers } \\
\text { 26. get others to dislike }\end{array}$ \\
\hline
\end{tabular}

Note:- Items 2, 12, and 25 are not in original version of the DIAS (Björkqvist, Lagerspetz, \& Österman, 1992).

\section{Procedure}

During the scheduled lesson, the researcher and class teacher distributed surveys to consenting students. Students were told to ask the researcher for assistance at any time if they experienced difficulties with the questionnaire. The researcher also reinforced the anonymity of the process and students' right to decline or cease participation at any time. Participants were told of the importance of truthful responses and that they were to answer the questions without conferring or copying. The class teacher, who remained in the classroom during data collection, gave those students who had declined to participate other quiet activities. Completed surveys were collected by the researcher and sealed in unmarked envelopes; the classroom survey process took on average approximately 45 minutes.

\section{RESULTS}

\section{Hypothesis Testing}

A series of one-way analysis of covariance (ANCOVA) test was performed to investigate gender differences in self-reported bullying behaviour. In considering the dependent variable subscales separately, it is apparent from Table 4 that boys showed significantly higher levels of physical and of verbal bullying than girls, supporting Hypotheses 1 and 3. Then, girls showed significantly higher levels of indirect bullying than boys, supporting hypothesis 5 . 
Table 4: The Relation of Respondent's Gender with Physical Bullying, Verbal Bullying and Indirect Bullying

\begin{tabular}{|c|c|c|c|c|c|c|c|c|c|}
\hline & & \multirow[t]{2}{*}{$\mathrm{N}$} & \multirow[t]{2}{*}{ Mean } & \multirow{2}{*}{$\begin{array}{c}\text { Std. } \\
\text { Deviation }\end{array}$} & \multirow{2}{*}{ Std. Error } & \multicolumn{2}{|c|}{$\begin{array}{l}95 \% \text { Confidence } \\
\text { Interval for Mean }\end{array}$} & \multirow[t]{2}{*}{ Minimum } & \multirow[t]{2}{*}{ Maximum } \\
\hline & & & & & & $\begin{array}{l}\text { Lower } \\
\text { Bound }\end{array}$ & $\begin{array}{l}\text { Upper } \\
\text { Bound }\end{array}$ & & \\
\hline \multirow{3}{*}{$\begin{array}{l}\text { Physical } \\
\text { Bullying }\end{array}$} & Boys & 60 & 1.9905 & .62843 & .08113 & 1.8281 & 2.1528 & 1.00 & 3.57 \\
\hline & Girls & 44 & 1.5417 & .29427 & .04436 & 1.4522 & 1.6311 & 1.00 & 2.14 \\
\hline & Total & 104 & 1.8006 & .55858 & .05477 & 1.6920 & 1.9092 & 1.00 & 3.57 \\
\hline \multirow{3}{*}{$\begin{array}{l}\mathrm{V} \text { e r b a } 1 \\
\text { Bullying }\end{array}$} & Boys & 60 & 2.1133 & .56131 & .07247 & 1.9683 & 2.2583 & 1.00 & 4.00 \\
\hline & Girls & 44 & 1.8273 & .45360 & .06838 & 1.6894 & 1.9652 & 1.20 & 2.80 \\
\hline & Total & 104 & 1.9923 & .53530 & .05249 & 1.8882 & 2.0964 & 1.00 & 4.00 \\
\hline \multirow{3}{*}{$\begin{array}{l}\text { Indire c t } \\
\text { Bullying }\end{array}$} & Boys & 60 & 22.9333 & 6.44893 & .83255 & 21.2674 & 24.5993 & 14.00 & 40.00 \\
\hline & Girls & 44 & 25.2955 & 5.05587 & .76220 & 23.7583 & 26.8326 & 17.00 & 39.00 \\
\hline & Total & 104 & 23.9327 & 5.98909 & .58728 & 22.7680 & 25.0974 & 14.00 & 40.00 \\
\hline
\end{tabular}

Therefore, Hypothesis 1 predicted that boys would report significantly higher mean scores of direct bullying than girls, and results showed clear support for this hypothesis. These results correspond with those of Owens and MacMullin who used a peer-estimation method based on the DIAS (13) with a similar sample and found that boys used significantly more physical and verbal aggression (i.e., Direct aggression in the present study) than girls.
A series of one-way analysis of covariance (ANCOVA) test was performed to investigate gender differences in self-reported victimization behaviour. In considering the dependent variable subscales separately, it is apparent from Table 5 that boys showed significantly higher levels of physical and of verbal victimization than girls, supporting Hypotheses 2 and 4. Then, girls showed significantly higher levels of indirect victimization than boys, supporting hypothesis 6 .

Table 5: The Relation of Respondent's Gender with Physical Victimization, Verbal Victimization and Indirect Victimization

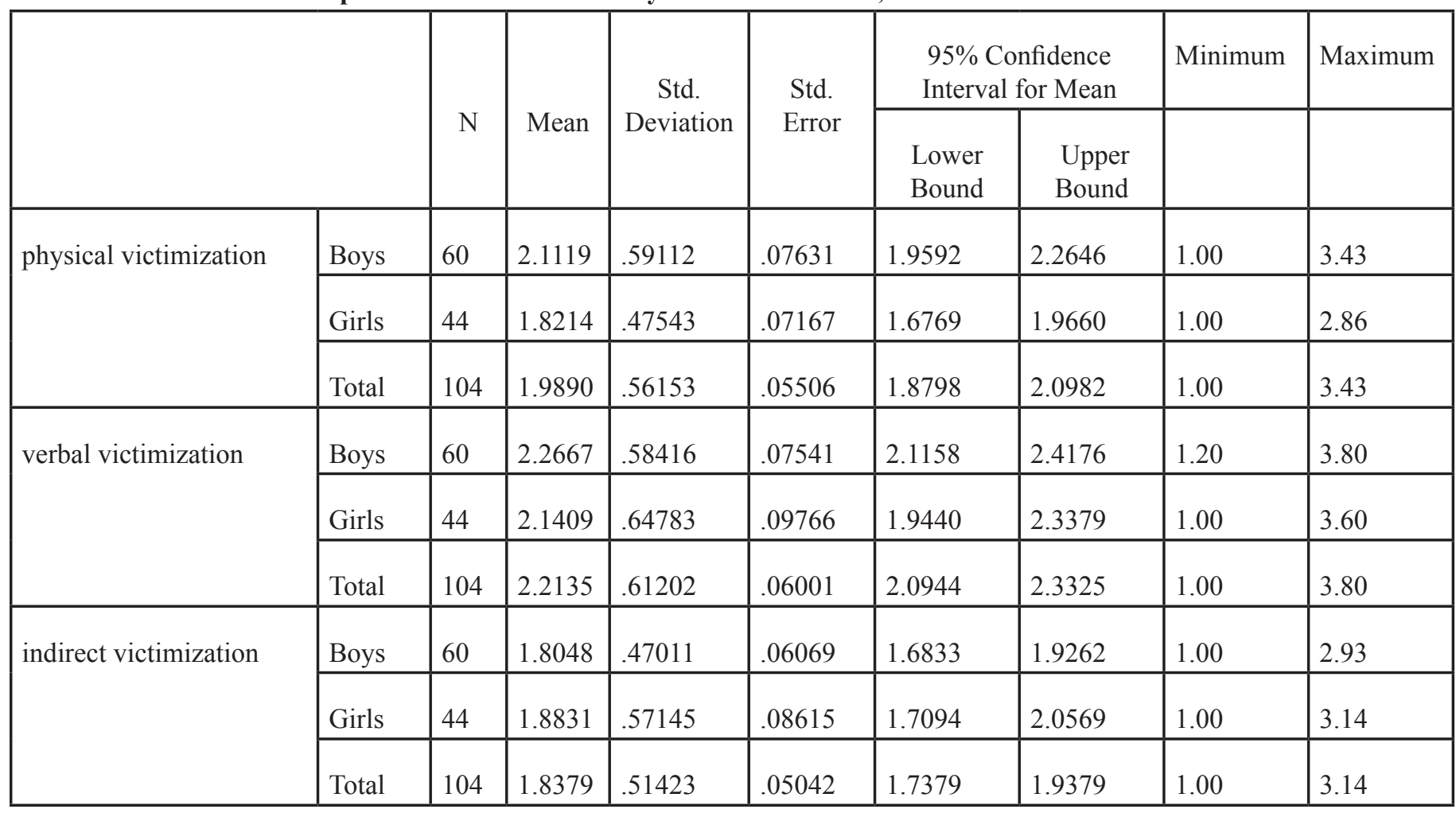


These findings converge with the large body of research that has consistently found that adolescent girls typically exhibit more indirect aggressive behavior than boys. Other studies using peer-nomination and peer-ratings have also found that "girls exhibit more indirect aggressive behavior than boys". ${ }^{20}$ Of note, particularly in terms of the prediction regarding indirect victimization is that a recent study that employed a self-report questionnaire based on the DIAS with a similar sample to the present study also found "girls to experience significantly higher levels of indirect victimization than boys". ${ }^{21}$

Furthermore, the findings of the present study correspond with and provide support for A. H. Eagly's social role theory, which proposes that "gender differences in social behavior occur because males are more agentic (instrumental, masculine) and females are more communal (expressive, feminine) in their behavior". ${ }^{22}$ Aggression, as defined and measured in the present study, can be categorized into direct (physical, verbal) and indirect (or relational/social) forms, with direct aggression corresponding with agentic behaviors and indirect with the communal behaviors of social role theory. The findings of the present study that males exhibited more direct agentic bullying behavior and girls more indirect communal bullying behavior converges with the pattern of gender differences in behavior that one would expect according to social role theory. In summary, gender differences in both direct and indirect aggression were as predicted and in accordance with previous research and social role theory.

\section{CONCLUSION}

Thus, bullying is a type of aggression. It is intentional and between imbalance of power. This study discussed the findings of analyses that explored the relationships between bullying and victimization in adolescents, whilst also considering prevalence rates. Generally speaking, gender differences in bullying and victimization were as expected and as social role theory and previous research would predict, with boys reporting higher direct and overall levels of bullying and victimization than girls. Similarly, and in accordance with the literature, girls reported higher levels of indirect bullying and victimization than boys are.

\section{REFERENCES}

1. Dake JA. The Nature and Extent of Bullying at School. Journal of School Health 2003;171-179.

2. Olweus D. Annotation:Bullying at School:basic Facts and Effects of a School Based Intervention Program. Journal of Child Psychology and Psychiatry 1994;1171-1190.

3. Hoover JH. Bullying: Perceptions of sdoloscent victims in the midwestern U.S.A. School Psychology International 1992;13:5-16.

4. Batsche GM. Bullies and their victims:Understanding a pervasive problem in the schools. School Psychology Review 1994;23:165-174.
5. Slee PT. Situational and interpersonal correlates of anxiety associated with peer victimization. Child Psychology and Human Development 1994;25:97-107.

6. Farrington DP. Childhood aggression and adult violence: Early precursors and later-life outcomes. The development and treatment of children aggression 1991;5-29.

7. Timmerman G. Sexual harassment of adolescents perpetrated by teachers and by peers: An exploration of the dynamics of power, culture, and gender in secondary schools. Sex Roles 2003;48:231-244.

8. Pellegrini AD. A longitudinal study of bullying, dominance, and victimization during transition from primary school through secondary school. British Journal of Development Psychology 2002;20:259-280.

9. Smith PK. Bullying in schools: Lessons from two decades of research. Agressive Behavior 2000;26:1-9.

10. Almeida AMT. The nature of school bullying: Acrossnational perspective Smith PK, MY, JTJ, OD, CR \& SP, editor. London:Routledge; 1999.

11. Lane DA. Bullying in school: The need for an integrated approach. School Psychology International 1989;10:211-215.

12. Pellegrini AD, Smith PK. Physical activity play: The nature and function of a neglected aspect of play. Child Development 1998;69:577-598.

13. Björkqvist K. Direct and Indirect Aggression Scales (DIAS) Vasa, Finland: Department of Social Sciences, Abo Akademi University 1992.

14. Archer J. Sex differences in aggression in real-world settings: A meta-analytic review. Review of General Psychology 2004;291-322.

15. Eagly AH. Sex differences in social behavior: A social role interpretation Hillsdale, NJ: Lawrence Erlbaum 1987.

16. Eagly AH, Wood W. Explaining sex differences in social behavior: A meta-analytic perspective. Personality and Social Psychology Bulletin 1991;17:306-315.

17. Osterman K, Bjorkqvist K, Lagerspetz KMJ, Kaukiainen A, Landau SF, Fraczek A. Cross-cultural evidence of female aggression. Aggressive Behavior 1998;24:1-8.

18. Björkqvist $\mathrm{K}$. Of mice and woman:Aspect of female aggression. In Björkqvist K. New trends in the study of female aggression. San Diego, CA: Academic Press 1992;3-16.

19. Gravetter FJ, Forzano LB. Research methods for the bevavioural sciences California: Wadsworth/Thomson Learning, Inc 2003.

20. Lagerspetz KMJ, Bjorkqvist K, Berts M, King E. Is indirect aggression typical of females? Gender differences in aggressiveness in 11-to 12-years old children. Aggressive Behavior 1988;14:403-414.

21. Owens L, Shute R, Slee P. In the eye of the beholder: Girls', boys' and teachers' perceptions of boys' aggression to girls. International Education Journal 2005;5:142-151.

22. Eagly AH. Sex differences in social behavior: A social role interpretation Hillsdale, NJ: Lawrence Erlbaum; 1987. 